\title{
Palatability and chemical defense of eggs, embryos and larvae of shallow-water antarctic marine invertebrates
}

\author{
James B. McClintock ${ }^{1, *}$, Bill J. Baker ${ }^{2}$ \\ ${ }^{1}$ Department of Biology, University of Alabama at Birmingham, Birmingham, Alabama 35294-1170, USA \\ ${ }^{2}$ Department of Chemistry, Florida Institute of Technology, Melbourne, Florida 32901, USA
}

\begin{abstract}
The present study examines aspects of palatability and chemical defense in the early life history stages of 7 common species of shallow-water antarctic marine invertebrates with contrasting modes of reproduction. These included the spawned eggs and larvae of a sea urchin and the intraovarian eggs of a sea star, both with planktotrophic larvae, and the lecithotrophic embryos and larvae of 3 sea stars with either brooding or broadcasting modes of reproduction. In addition, a sponge and a nudibranch with brooded lecithotrophic embryos and egg nbbons, respectively, were investigated. Ovaries containing eggs, spawned eggs, and developing embryos or larvae were tested for their palatability against 3 common sympatric predators representing widely disparate feeding patterns: the sea star Odontaster validus (a benthic scavenger), the sea anemone Isotealia antarctica (a benthic filter feeder and opportunistic carnivore) and the amphipod Paramoera walkeri (a benthic and water column scavenger). Alginate feeding pellets containing hydrophilic and lipophilic extracts of spawned eggs of the broadcasting planktotrophic sea urchin Sterechinus neumayeri and ovaries containing developing eggs of the broadcasting planktotrophic sea star $O$. validus were readily consumed by all 3 predators. Pellets containing hydrophilic and lipophilic extracts of 4 -armed echinoplutei larvae of $S$. neumayeri offered to the sea anemone 1 . antarctica were also consumed, indicating a lack of chemical defense. In contrast, at least 1 of the 3 predators demonstrated feeding inhibition to eggs, embryos, larvae or their hydrophilic or lipophilic extracts in the remaining 5 lecithotrophic species. In the lecithotrophic sea star Diplasteria brucei we demonstrate that the basis of rejection is chemically mediated. It is likely that rejection among the other 4 lecithotrophic species is also chemically based as eggs, embryos and larvae are conspicuous and high in energy content, lack morphological defenses, and are immobile or sluggish swimmers. Our findings indicate predators display species-specific feeding deterrent responses and support observations that lecithotrophic embryos or larvae may be particularly well suited to chemical defenses. Chemical defense in early life history stages may be especially important in shallow antarctic seas where species with lecithotrophic development patterns are relatively common, and where conspicuous yolky embryos or larvae may spend a considerable period of time developing in benthic or pelagic environments prior to recruitment.
\end{abstract}

KEY WORDS: Chemical defense Antarctica Planktotroph - Lecithotroph - Embryo Egg

\section{INTRODUCTION}

Little information is available on the palatability and chemical defense of marine invertebrate eggs, embryos or larvae (Bakus et al. 1986, Paul 1992, Pawiik 1993, Hay 1996), other than several studies examining temperate and tropical marine invertebrate larvae (Lucas et al. 1979, Young \& Bingham 1987, Lindquist et

\footnotetext{
•E-mail: mcclinto@uab.edu
}

al. 1992, Lindquist 1996, Lindquist \& Hay 1996). No ecologically relevant information is available for early life history stages of polar marine invertebrates (McClintock \& Vernon 1990). Such information is important because models for the evolutionary selection of life history patterns in marine invertebrates make assumptions about patterns of mortality of offspring (Mileikovsky 1971, Vance 1973, Strathmann \& Strathmann 1982, Jablonski \& Lutz 1983, Strathmann 1985. Emlet et al. 1987, Roughgarden et al. 1988, 
Roughgarden 1989, Alexander \& Roughgarden 1996). These models generally assume that eggs, embryos and larvae are vulnerable to predators, and have primarily considered marine invertebrates with planktotrophic modes of development

Marine invertebrates display a variety of reproductive modes. Generally either large numbers of very small eggs are released into the water column where they become feeding planktotrophic larvae, or much smaller numbers of larger eggs are either protected (brooded) by the parent or held within an egg mass where they develop through non-feeding lecithotrophic embryonic or larval stages (Vance 1973). While less common, some marine invertebrates release large yolky eggs, embryos or larvae into the water column, where in temperate and tropical waters they typically spend a short period of time before settlement (Strathmann 1985). In shallow antarctic marine waters, brooding was once thought to be the predominant reproductive mode in marine invertebrates (Thorson 1950). More recently, evidence has been presented indicating that the incidence of pelagic development in antarctic marine invertebrates is similar to that found in temperate and tropical marine waters (Pearse et al. 1991), and that while non-feeding modes of development predominate (Jablonski \& Lutz 1983), a surprisingly large number of antarctic species release large yolky embryos into the water column (Pearse et al. 1991). Large eggs, embryos and larvae of marine invertebrates may be particularly vulnerable to predation (Lindquist et al. 1992, Lindquist 1996, Lindquist \& Hay 1996) and especially so in shallow antarctic waters where developmental rates are reduced by several orders of magnitude (Clarke 1982, Bosch et al. 1987, Bosch 1989, Bosch \& Pearse 1990, Pearse et al. 1991) resulting in offspring spending months on the benthos or in the water column before becoming juveniles. A wide suite of antarctic predators including filter feeders and watercolumn and benthic scavengers are likely to provide sufficient selection for the evolution of defensive traits in eggs, embryos or larvae. While water-column invertebrate grazers can be spatially or temporally patchy, they can be extremely abundant when present (Garrison 1991). The lecithotrophic eggs, embryos and larvae of antarctic marine invertebrates would be particularly vulnerable as they are often conspicuous due to their large size (Bosch 1989, Pearse et al. 1991), lack the swimming ability of planktotrophic larvae (Bosch et al. 1987, Bosch \& Pearse 1990), and are attractive prey due to their high energy content (McClintock \& Pearse 1986).

The present study examines whether the intraovarian and spawned eggs, and developing embryos or larvae, of a suite of antarctic marine invertebrates with contrasting modes of reproduction are palatable to common sympatric predators that employ a variety of feeding tactics. Where sufficient amounts of material could be attained, organic extracts were tested in feeding pellets to determine whether there was a chemical basis to feeding inhibition.

\section{MATERIALS AND METHODS}

Invertebrate species representative of a variety of reproductive modes and that were sexually mature during the antarctic austral spring (October and November, 1996) were targeted for collections using SCUBA. The common sea star Odontaster validus and the common regular sea urchin Sterechinus neumayeri, both with broadcasting planktotrophic modes of reproduction, were collected from 20 to $30 \mathrm{~m}$ depth in front of McMurdo Station ( $77^{\circ} 51^{\prime} \mathrm{S}, 164^{\circ} 40^{\prime} \mathrm{E}$ ) and fiom 3 to $10 \mathrm{~m}$ depth at Cape Evans $\left(77^{\circ} 38^{\prime} \mathrm{S}\right.$, $164^{\circ} 24^{\prime} E$ ), respectively (see McClintock et al. 1988 and Brey et al. 1995 for map and descriptions of collection sites). The remaining species examined had lecithotrophic miodes of teproduction. The sea stars Diplasterias brucei (an external brooder) and Perknaster fuscus (a pelagic lecithotroph) and the nudibranch Tritoniella belli (lays egg ribbons) were collected from 25 to $35 \mathrm{~m}$ depth near McMurdo Station at Arrival Heights. The sponge Isodictya setifera (an internal brooder that has an abbreviated larval stage) was collected in $33 \mathrm{~m}$ of water near Little Razorback Island $\left(77^{\circ} 40^{\prime} \mathrm{S}, 163^{\circ} 24^{\prime} \mathrm{E}\right)$, while the sea star Psilaster charcoti (a pelagic lecithotroph) was collected from $30 \mathrm{~m}$ depth at New Harbor $\left(77^{\circ} 34^{\prime} \mathrm{S}, 163^{\circ} 35^{\prime} \mathrm{E}\right)$ on the western side of McMurdo Sound.

The predators employed in feeding assays were chosen so as to represent a variety of feeding modes and were sufficiently abundant to represent a significant predation threat to eggs, embryos and larvae. The common omnivorous sea star Odontaster validus (radius $=5$ to $7 \mathrm{~cm}$ ) (McClintock et al. 1988, McClintock 1994) was collected ( $\mathrm{n}=50$ to 80 ) as indicated above. This species was selected because Dayton et al. (1974) describes it as an important 'larval filter' through which all settling larvae and early juveniles must pass. Also collected from Arrival Heights $(30 \mathrm{~m}$ depth) were individuals of the extremely abundant filter feeding and opportunistically carnivorous sea anemone Isotealia antarctica ( $\mathrm{n}=20$, disc diameter 10 to $12 \mathrm{~cm}$ ) (Dayton et al. 1974). Swarms ( $>400$ ) of the common omnivorous amphipod Paramoera walkeri (2 to $5 \mathrm{~mm}$ length) were collected near Little Razorback Island in $3 \mathrm{~m}$ depth by a diver using a small aquarium net $(15 \times 10 \mathrm{~cm}$ mouth; 3 swipes through the water column collected over 700 ind.). These are both seasonally benthic or sea-ice associated and may also fill the 
water column and consume water-column, sea-iceassociated and benthic plants and animals (phytoplankton, copepods, sponges; Rakusa-Suszczewski 1972, Garrison 1991).

Mature gametes were obtained from the sea urchin Sterechinus neumayeri (mean egg diameter $=180 \mu \mathrm{m}$; orange eggs) by intracoelomic injection of $0.5 \mathrm{M} \mathrm{KCl}$ through the peristomial membrane (Bosch et al. 1987). Unfertilized eggs as well as larvae reared according to the methods of Bosch et al. (1987) to the 4-armed echinoplutei stage (approximately 300000 20-day-old larvae; mouth just becoming functional) were extracted for feeding pellet assays (see below). Mature gametes of the sea stars Psilaster charcoti (mean egg diameter $=750 \mu m_{i}$ orange eggs) and Perknaster fuscus (mean egg diameter $=1200 \mu \mathrm{m}$; orange eggs) were obtained by intracoelomic injection of $10^{-5} \mathrm{M}$ 1-methyladenine (Stevens 1970). Both newly fertilized embryos and swimming larvae (larvae 10-15 and 13-18 d old, respectively) were tested for feeding deterrence. Larvae were reared in 11 glass beakers placed in a cold room $\left(0^{\circ} \mathrm{C}\right)$ on a shaker table. No mortality was observed in larval cultures during the rearing period. Rejected larvae that made physical contact with predators were collected and returned to separate 1 l glass beakers maintained at $0^{\circ} \mathrm{C}$ on the shaker table, and subsequent mortality examined over a $7 \mathrm{~d}$ period. Control larval cultures comprised of identical larvae that had not contacted predators exhibited no mortality during this $7 \mathrm{~d}$ period. As the common sea star Odontaster validus spawns annually in late winter or very early spring (Pearse 1965), it was not possible to collect spawned eggs. Nonetheless, as $O$. validus has oocytes that ripen over a 2 yr period (Pearse 1965), small pieces of the ovaries containing developing eggs were dissected from adult females and tested for their palatability. While the feeding deterrent properties of developing ovaries do not definitively demonstrate a lack or presence of chemical defense in eggs (there could be contamination from nutritive or structural tissues), it does provide some measure of the likelihood of egg palatability. Brooded embryos of the sea star Diplasterias brucei (mean egg diameter $=3400 \mu \mathrm{m}$; orange eggs) were removed from the oral surfaces of 3 brooding females. These were tested both as intact embryos and then, after extraction, as feeding pellets. Brooded eggs gently teased with forceps from the tissues of the sponge Isodictya setifera (mean egg diameter $=875 \mu \mathrm{m}$; yellow eggs) were tested for palatability. In addition, small pieces of egg ribbons containing developing embryos of the nudibranch Tritoniella belli (mean egg diameter $=600 \mu \mathrm{m}$; white eggs) were also tested for palatability.

When sufficient amounts of material were available, hydrophilic and lipophilic extracts were prepared and tested in feeding pellets. Eggs, embryos or larvae were weighed and then lyophilized and re-weighed. The freeze dried material was then extracted first with dichloromethane/methanol (1:1) $(2 \times 25 \mathrm{ml})$ for $12 \mathrm{~h}$ twice. Evaporation of the solvents yielded a lipophilic extract. A hydrophilic extract was prepared by subsequent extraction of the freeze dried material with methanol/water (1:1) in a similar manner. Extract dry weights were determined. Alginate pellets containing dry krill powder (5\% by weight) as a feeding stimulant were loaded with extract such that the total volumetric concentration of extract in pellets was similar to that in the wet tissue from which it was extracted. To convert gravimetric to volumetric measurements we employed a density value of 1.0, which we based on direct volumetric measurements of known wet weights of batches of eggs of the sea urchin Sterechinus neumayeri and embryos of the sea star Diplasterias brucel. As the eggs, embryos and larvae of antarctic marine invertebrates are very high in energy-rich organic constituents (McClintock \& Pearse 1986), alginate feeding pellets containing a $5 \%$ krill powder were likely less nutrient-rich, yet contained sufficient levels of feeding stimulant to induce a consistent feeding response. Experimental pellets containing extracts and control pellets containing only krill and the solvent carrier were spherical and measured $2 \mathrm{~mm}$ in diameter. Control alginate pellets were prepared so as to be similar in shape and size to eggs, embryos, larvae or small pieces of tissue.

Feeding deterrent assays were tailored to each specific predator. In all feeding assays with all 3 predators tested, only individuals that first consumed a control pellet were presented an opportunity to subsequently feed on an experimental pellet, egg, embryo, larva or tissue (Lindquist \& Hay 1996). In almost all cases individual predators consumed control pellets. Feeding deterrence was measured in the sea star Odontaster validus using a modification. of the methods described in McClintock et al. (1994a, b). Experimental and control pellets, eggs, embryos, larvae or tissue pieces were placed on the extended tube-feet within the ambulacral groove equidistant between the arm tip and the oral opening of a single arm. Individuals that were tested had positioned themselves at the air-water interface of a large $3 \mathrm{~m}$ diameter circular water tank (7000 1) equipped with running ambient seawater $\left(-1^{\circ} \mathrm{C}\right)$. No individual was tested more than once in a given treatment ( $\mathrm{n}=9$ to 13 ). As with all predators tested, individuals were held in the laboratory for at least $1 \mathrm{wk}$ prior to feeding assays to standardize nutritional condition. As sea stars are capable of surviving and behaving normally without regular feeding for long periods of time (Jangoux 1982), consumption of control pellets by sea stars rotated regularly through 
assays was considered sufficient for maintenance during the experimental period ( 2 to $3 \mathrm{wk}$ ). Acceptance was considered to be when individuals moved the pellet, egg, embryo, larva or tissue to the oral opening where the extruded cardiac stomach was generally displayed. Rejection was considered to be when over a 20 min period individuals: (1) dropped the pellet, egg, embryo, larva or tissue, or (2) moved the pellet, egg, embryo, larva or tissue away from the mouth towards the arm tip or out of the ambulacral groove. Significant differences between levels of rejection or acceptance between control and experimental treatments were determined using a Fisher's exact test (Zar 1996).

Feeding deterrence was measured in the sea anemone Isotealia antarctica by placing 20 individuals in a seawater table $(1 \times 2 \mathrm{~m})$ equipped with ambient flowing seawater $\left(-1^{\circ} \mathrm{C}\right)$ to a depth of $10 \mathrm{~cm}$. Each individual was isolated within a PVC ring $(20 \mathrm{~cm}$ diameter, $15 \mathrm{~cm}$ height) during feeding trials that effectively cut off any water flow. No individual was tested in any given treatment more than once. Each pellet, egg, embryo, larva or tissue was placed gently in contact with an outstretched tentarle using a pair of forceps or a disposable glass pipette. The immediate response was for the tentacle to wrap itself around the pellet. Acceptance was considered to be when individuals moved the pellet, egg, embryo, larva or tissue to the mouth with subsequent ingestion. Rejection was considered to be when over a 20 min period: (1) individuals released the pellet, egg, embryo, larva or tissue, (2) individuals placed the pellet, egg, embryo, larva or tissue on the oral disc but not in the mouth (in such cases pellets eventually rolled off the disc), or (3) the tentacle unwrapped from around the pellet, egg, embryo, larva or tissue and the potential prey item remained hanging from the underside of the tentacle by mucus. Significant differences between levels of rejection or acceptance were determined using a Fisher's exact test. Between bioassays, sea anemones were fed a maintenance diet of 1 large freeze dried krill (length $=20$ to $25 \mathrm{~mm}$ ) per week per individual.

Feeding deterrence in the amphipod Paramoera walkeri was measured for each experimental pellet, egg, embryo, larva or tissue by adding 10 individual amphipods to each of twenty $250 \mathrm{ml}$ plastic Erlenmeyer screw-top wide-mouth flasks containing $150 \mathrm{ml}$ of fresh ambient seawater. Ten flasks contained 3 control feeding pellets and the remaining ten flasks contained either 3 experimental pellets, eggs, embryos, larvae or small pieces of tissue. During feeding trials the flasks were placed in a $2 \mathrm{~m}$ diameter circular tank equipped with running seawater. Flasks floated at the air-water interface and remained near ambient seawater temperature $\left(-1^{\circ} \mathrm{C}\right)$ during the experiment. The total number of amphipods grazing on the surfaces of the 3 pellets, eggs, embryos, larvae or tissues were counted after a $20 \mathrm{~min}$ period. While it was not possible to directly observe grazing activities, the pellets, eggs, embryos, larvae or tissues that attracted amphipods to their surfaces were clearly consumed over time and were all examined after a $24 \mathrm{~h}$ grazing period for clear evidence of consumption. Control treatments consisting of presenting amphipods 3 pellet-sized stirring stones or 3 alginate pellets containing no krill or solvent carrier were also conducted. Inhibition of feeding was measured by comparing arcsine transformed (normalized) percentages of individuals grazing in control and experimental treatments using a Student's $t$-test (n $=10)$. Amphipods $(n>700)$ were maintained between bioassays in a single large polyethylene container (10 l) kept at ambient seawater temperature. A small amount of conspecific mortality and turnover in the container provided scavenging individuals an adequaie source of nutrients during the short duration of the bioassays ( 2 to 3 wk).

\section{RESULTS}

The omnivorous sea star Odontaster validus displayed feeding deterrence to eggs, embryos, larvae, or egg mass pieces of 5 of the 7 species examined (Fig. 1) Krill feeding pellets containing ecologically relevant concentrations of hydrophilic and lipophilic extracts of fresh spawned eggs of the common sea urchin Sterechinus neumayeri were readily consumed. $O$. validus also readily consumed pieces of its own maturing ovaries containing developing oocytes. The large brooded embryos of the sea star Diplasterias brucei were unpalatable to $O$. validus $(p<0.05)$, and significant feeding deterrence $(p<0.05$ ) was associated with the hydrophilic fraction of the organic extract from these embryos; $35 \%$ of the pellets containing a lipophilic extract were also rejected (Fig. 1). The lecithotrophic embryos and larvae of the sea stars Perknaster fuscus and Psilaster charcoti were never consumed $(p<0.01$ ) by $O$. validus, indicating they were highly unpalatable. Rejected larvae of both $P$. fuscus and $P$. charcoti ( $\mathrm{n}=10$ larvae per species) held in culture were all still healthy and swimming at the end of a 7 d period. Both the eggs of the sponge Isodictya setifera and pieces of the egg ribbons of the nudibranch Tritoniella belli were also unpalatable $(\mathrm{p}<$ $0.05)$ to $O$. validus.

The common sea anemone Isotealia antarctica, which filters prey from the water column and opportunistically attacks benthic prey, showed feeding deterrence to eggs, embryos, or larvae of 4 of the 7 species tested (Fig. 2). Krill pellets containing hydrophilic and lipophilic extracts of the eggs and larvae of the 


\section{PREDATOR - ODONTASTER VALIDUS}

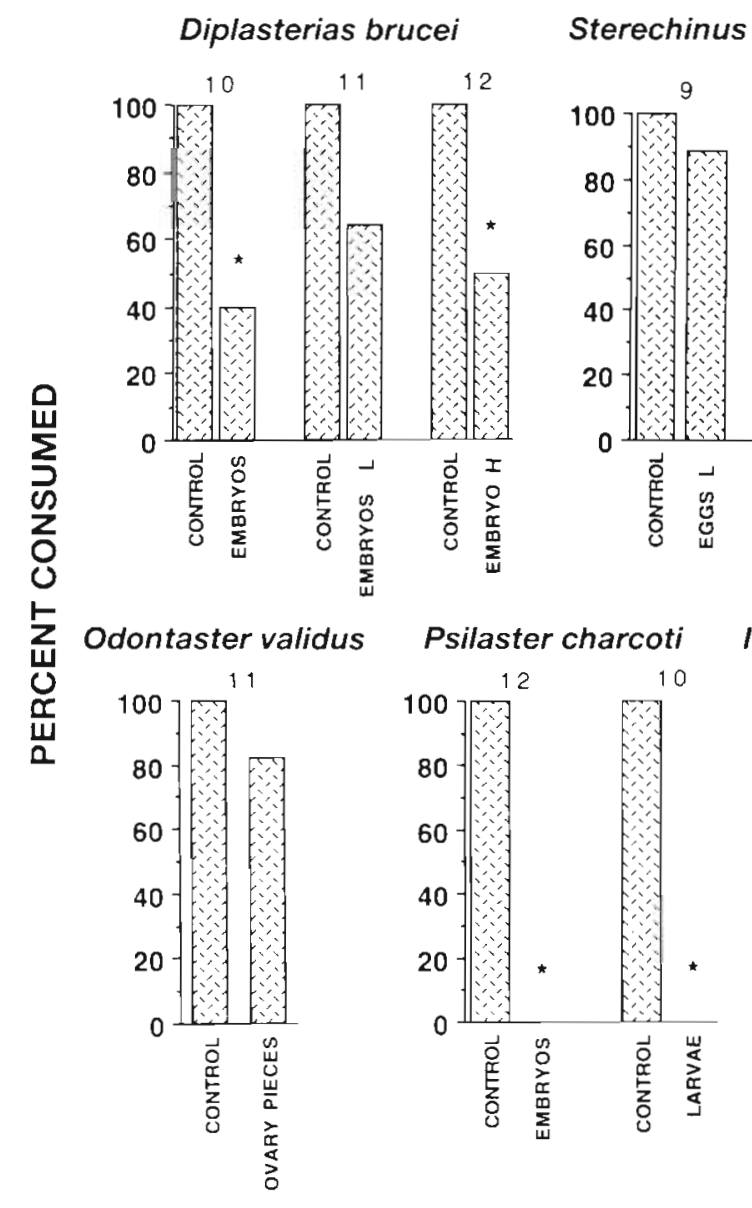

Perknaster fuscus

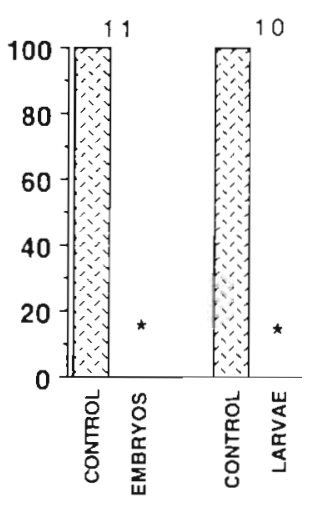

Fig. 1. Percentages of marine invertebrate eggs, embryos, larvae, ovary pieces, egg mass pieces, or alginate krill pellets with extracts (L: lipophilic extract; H: hydrophilic extract) carried along the ambulacral groove by tube feet to the oral opening and extruded cardiac stomach of the sea star Odontaster validus. In all assays, controls consisted of alginate krill pellets, and when tested against extracts, the appropriate solvent carrier. Numbers of replicates are shown at the top of each pair of bars. Asterisks indicate experimental treatments that are significantly different from controls $(p<0.05)$

common sea urchin Sterechinus neumayeri, as well as pieces of the ovaries of the common sea star Odontaster validus, were readily consumed. Moreover, pieces of the egg ribbons of the nudibranch Tritoniella belli were palatable (Fig. 2). While only $15 \%$ of the lecithotrophic embryos of the brooding sea star Diplasterias brucei were rejected by $I$. antarctica, significant $(p<0.05)$ rejection was detected for krill pellets containing the lipophilic fraction of extracted brooded embryos. Significant rejection $(p<0.05)$ was also detected for the embryos (50\% rejection) and for the larvae ( $<<0.01 ; 100 \%$ rejection) of the lecithotrophic sea star Perknaster fuscus. None of the embryos or larvae of the lecithotrophic sea star Psilaster charcoti were consumed $(p<0.01)$, nor were eggs of the sponge Isodictya setifera $(\mathrm{p}<0.01)$. Seventy-five percent ( 9 of 12) of the $P$. fuscus larvae rejected by sea anemones were healthy and swimming after a $7 \mathrm{~d}$ period. Ninetyone percent (10 of 11 ) of the rejected $P$. charcotilarvae were healthy and swimming after a $7 \mathrm{~d}$ period.

The amphipod Paramoera walkeri displayed feeding deterrence in response to the eggs, embryos or larvae of 3 of the 7 species (Fig 3). Extracts of the eggs of the sea urchin Sterechinus neumayeri were palatable, as were pieces of the developing ovaries of the sea star Odontaster validus. The large brooded embryos of the sea star Diplasterias brucei were also readily grazed, with embryos entirely consumed after a $24 \mathrm{~h}$ period. Egg masses of the nudibranch Tritoniella belli were also grazed with the same frequency as control krill pellets. Significant $(p<0.01)$ feeding deterrence and strong swimming avoidance were noted against the lecithotrophic embryos and larvae of the sea stars Perknaster fuscus and Psilaster charcoti. As amphipods 


\section{PREDATOR - ISOTEALIA ANTARCTICA}

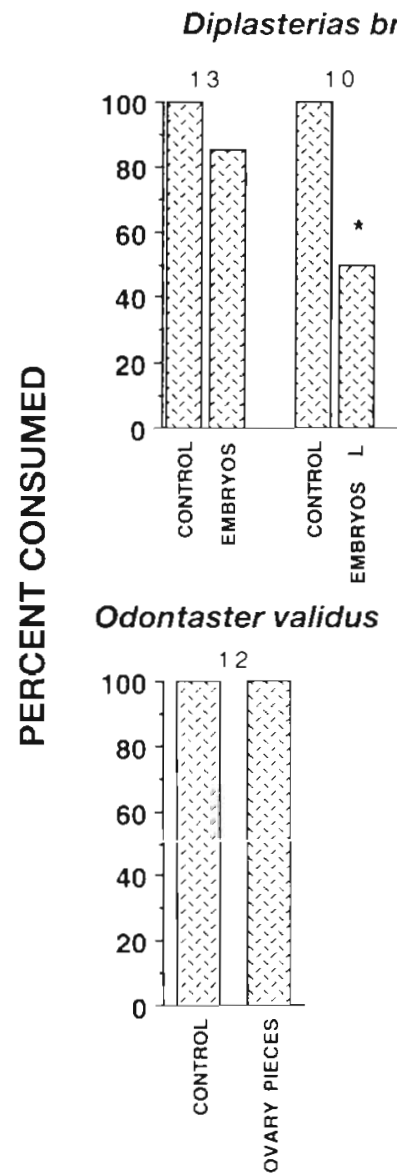

Sterechinus neumayeri

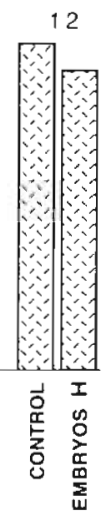

\section{Psilaster charcoti}

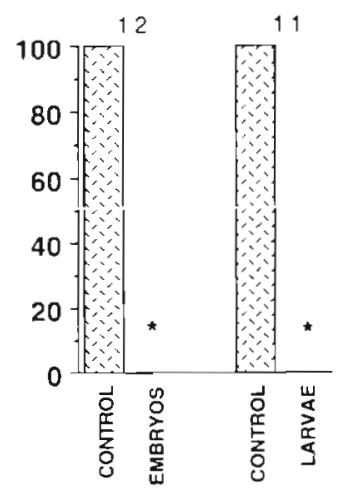

Perknaster fuscus
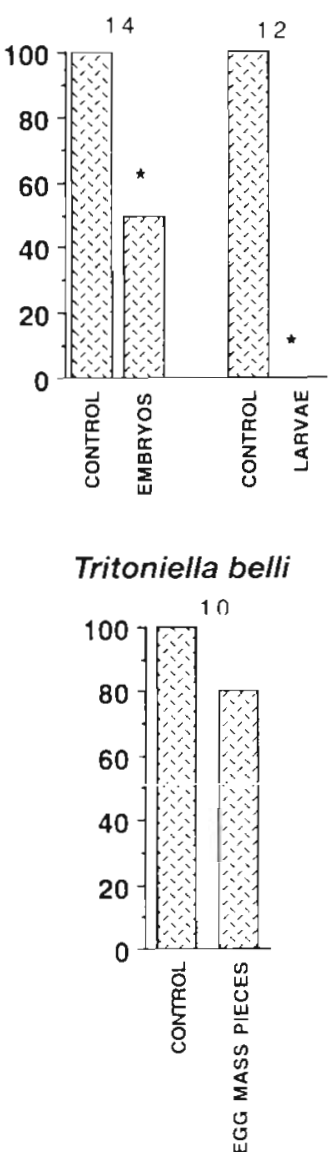

Fig. 2. Percentages of marine invertebrate eggs, embryos, larvae, ovary pieces, egg mass pieces, or alginate krill pellets with extracts (L: lipophilic extract; $\mathrm{H}$ : hydrophilic extract) passed from a tentacle to the mouth and ingested by the sea anemone Isotealia antarctica. In all assays, controls consisted of alginate krill pellets, and when tested against extracts, the appropriate solvent carrier. Numbers of replicates are shown at the top of each pair of bars. Asterisks indicate experimental treatments that are significantly different from controls $(p<0.05)$

did not make contact with embryos or larvae, no attempt was made to culture larvae over a $7 \mathrm{~d}$ period to evaluate how predator contact might influence survival. Amphipods presented small stirring pellets (stones) displayed very low frequencies of attachment behavior ( $8 \%)$, while those presented alginate pellets lacking krill and solvent carrier displayed low frequencies of grazing activities (22\%), levels of grazing on krill control pellets being 2- to 4 -fold higher (Fig. 3).

\section{DISCUSSION}

While larval survival and settlement rates are considered very important in mediating the population structures of marine invertebrates (e.g. Underwood \& Denley 1984, Gaines \& Roughgarden 1985, Roughgar- den et al. 1988, 1995, Olafsson et al. 1994), our knowledge of early benthic or planktonic stages is quite poor in comparison with later benthic components of the life cycle (Eckman 1996). Clearly, morphological or chemical defenses in eggs, embryos and larvae will have direct effects on rates of mortality (Rumrill 1990, Morgan 1995, Lindquist \& Hay 1996), and therefore indirect effects on dispersal and settlement (Okubo 1994, Shanks 1995). Studies that have modeled life history strategies of benthic marine invertebrates have generally contrasted larvae that are released (broadcasted) with those that are protected (brooded) (e.g. Thorson 1950 , Vance 1973, Valentine \& Jablonski 1983, Strathmann 1985, Emlet et al. 1987). Many of these studies assume that marine invertebrate larvae, particularly broadcasted larvae, are consumed by a variety of predators (Young \& Chia 1987). The present study 


\section{PREDATOR - PARAMOERA WALKERI}

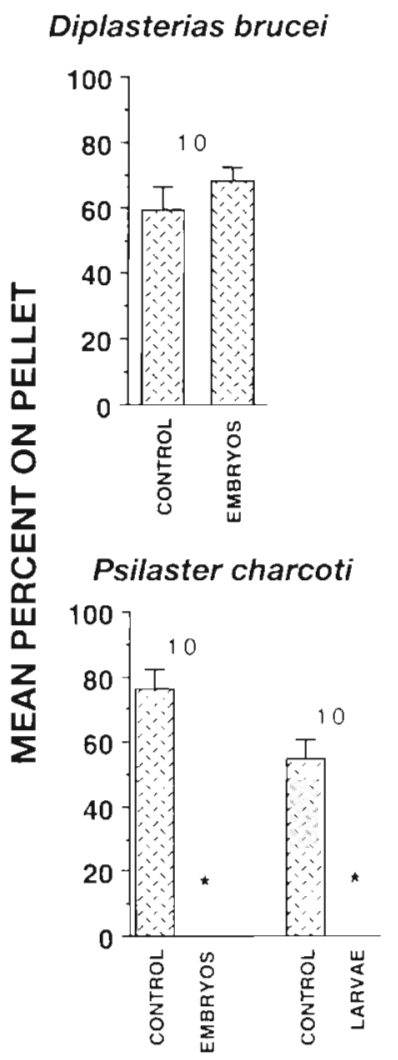

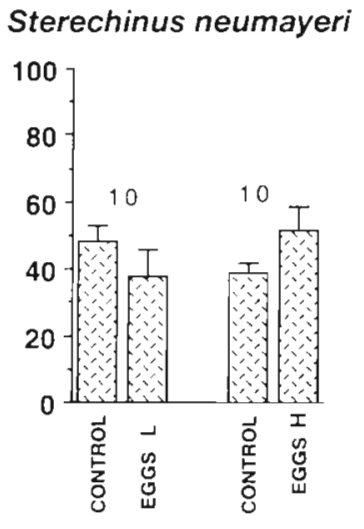

Isodictya setifera

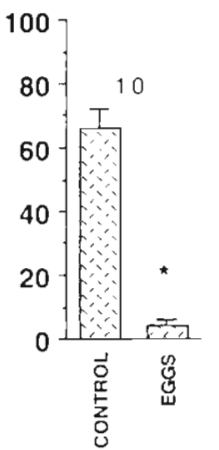

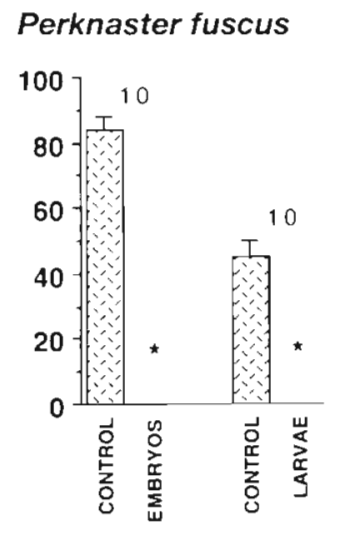

Tritoniella belli

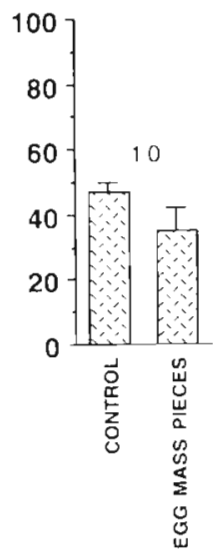

Odontaster validus
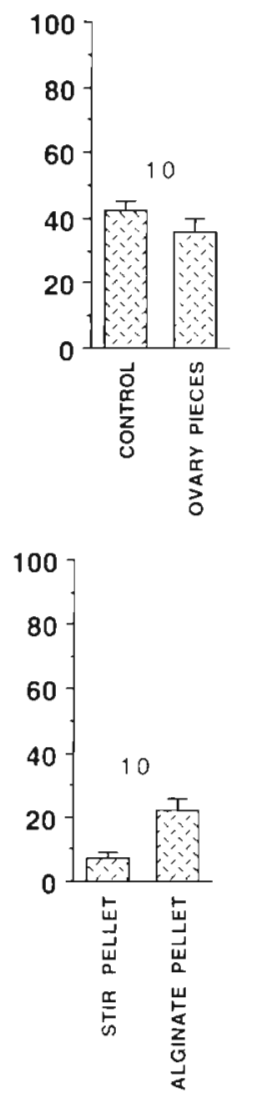

Fig. 3. Percentages of individuals of the amphipod Paramoera walkeri grazing on the surfaces of marine invertebrate eggs, embryos, larvae, ovary pieces, egg mass pieces, or alginate krill pellets with extracts (L: lipophilic extract; H: hydrophilic extract). In all assays (except for amphipods presented stirring stone pellets and alginate pellets) controls consisted of alginate krill pellets, and when tested against extracts, the appropriate solvent carrier. In each assay 10 amphipods were presented 3 eggs, embryos, larvae, ovary pieces, egg mass pieces or alginate krill pellets. Numbers of replicates are shown at the top of each pair of bars. Asterisks indicate experimental treatments that are significantly different from controls $(p<0.05)$

indicates that defenses occur in the eggs, embryos and larvae of antarctic marine invertebrates; all 5 lecithotrophic species had eggs, embryos or larvae that were unpalatable to at least 1 sympatric predator. Our findings support the recent observations of Lindquist (1996) and Lindquist \& Hay (1996) that brooded and pelagic lecithotrophic larvae of sponges, hydroids, bryozoans and corals are unpalatable to select sympatric corals, sea anemones and fish.

Antarctic marine invertebrates display a variety of reproductive modes including broadcasting both planktotrophic and lecithotrophic larvae as well as brooding embryos or provisioning them with an egg case or gelatinous mass (reviewed by Arnaud 1974 , Picken 1980, Pearse et al. 1991). Embryonic and larval development in antarctic marine invertebrates is extremely slow, a characteristic that may be related to low temperature (Clarke 1982, Bosch et al. 1987, Bosch \& Pearse 1990, Pearse et al. 1991). One consequence of a long development period is that embryos and larvae spend literally months on the benthos or in the plankton where they may be exposed to predators. A variety of studies in temperate and tropical systems have found that even larvae that spend considerably less time in the plankton are vulnerable to predation (Timko 1979, Oliver et al. 1982, Bailey 1984, Cowden et al. 1984, Bingham \& Walters 1989, Purcell 1989 , Morgan 1990). While small broadcasted planktotrophic larvae have the advantage of high numbers and large embryos are protected via brooding or by an egg case or a gelatinous mass, the production of large pelagic lecithotrophic embryos and larvae is enigmatic, as this combines both low fecundity with conspicuous long-term development in the plankton. 
Recent evidence suggests that contrary to the prediction of 'Thorson's Rule', pelagic lecithotrophy is not uncommon among antarctic marine invertebrates (Pearse et al. 1991)

In the present study we found that the pelagic lecithotrophic sea stars Perknaster fuscus and Psilaster charcoti produced both embryos and larvae that were highly unpalatable to sea star, sea anemone and amphipod predators. It is likely that the basis of feeding deterrence is chemical as these pelagic lecithotrophic embryos and larvae are: (1) conspicuous due to their large size, (2) not defended morphologically, (3) sluggish swimmers, and (4) rich in energy due to a high lipid and protein content (McClintock \& Pearse 1986). In contrast, ovaries containing planktotrophic eggs of the broadcasting sea star Odontaster validus and hydrophilic and lipophilic extracts of the planktotrophic eggs and 4-armed echinoplutei larvae of the broadcasting sea urchin Sterechinus neumayeri were readily consumed by all predators. However, Lucas et al. (1979) found that the planktotrophic larvae of the tropical sea star Acanthaster planci employ saponins to chemically defenci inemseives from piankivorous fish predation.

Neither of the predators that came in physical contact with swimming lecithotrophic larvae (the sea star Odontaster validus and the sea anemone Isotealia antarctica) caused high levels of post-contact larval mortality. None of the larvae of either Perknaster fuscus or $P$ silaster charcoti died after encountering sea star tubefeet, while limited mortality (9 to $25 \%$ mortality after $1 \mathrm{wk}$; most mortality in the first $2 \mathrm{~d}$ ) was observed in lecithotrophic larvae following physical contact with sea anemone tentacles. It is possible that these low levels of larval mortality were due to tissue damage caused by nematocysts. Lindquist (1996) also found high survivorship in tropical marine invertebrate larvae captured and then rejected by corals and sea anemones, and Lindquist \& Hay (1996) noted a similar trend in tropical marine invertebrate larvae rejected by fish predators.

While the immense fecundity of broadcasting planktotrophs may ensure that some larvae survive to metamorphosis in antarctic waters, it is likely that predation pressure in the water column may be sufficient to select for defense in larger conspicuous lecithotrophic embryos and larvae. Antarctic waters are characterized by abundant crustaceans that feed on small organisms under the sea ice (Garrison 1991), watercolumn zooplankton and gelatinous holoplanktonic predators that may be patchy in time and space but abundant within patches (Foster 1987, Harbison 1988), as well as sea-ice-associated predatory fishes (Eastman 1993). One of the predators we employed in the present study, the voracious amphipod Paramoera walkeri, occurs seasonally in extremely high density swarms in the water column as well as under the sea ice (Rakusa-Suszczewski 1972, C. Amsler pers. obs.). There is also evidence of antipredatory adaptations in antarctic holoplanktonic marine invertebrates. The pelagic antarctic pteropod Clione antarctica, which occurs in vast swarms, is chemically defended (Bryan et al. 1995), while the antarctic hyperiid amphipod Hyperiella dilatata has been shown to abduct and carry this pteropod as a chemical defense against fish predation (McClintock \& Jansson 1990). Some antarctic marine invertebrates spawn primarily during the dark winter months (see Pearse et al. 1991) and their larvae or brooded embryos may be under less predation pressure because visually oriented predators would be less effective. One hypothesis, yet to be tested, would be that greater percentages of eggs and larvae spawned at this time would be palatable.

There is ample evidence that predation pressure against marine invertebrate eggs, embryos and larvae exposed to antarctic benthic predators during spawning or settlement should be high (Dayton et al. 1974). In the shallow continental shelf waters of Antarctica, there are benthic predatory fish (Eastman 1993) and numerous benthic filter feeders that occur in extremely high abundance (Dell 1972, Dayton et al. 1974, Dayton \& Oliver 1977. White 1984). All of the invertebrate predators employed in the present study are excellent examples of antarctic circumpolar species that occur in dense populations. The amphipod Paramoera walkeri lives on shallow sand bottoms and moves seasonally to the sea ice community (Rakusa-Suszczewski 1972). During the austral spring it was observed to swarm near the benthos (C. Amsler pers. obs.) and benthic organisms have been found in gut samples (RakusaSuszczewski 1972). The sea anemone Isotealia antarctica also occurs in dense populations, in some areas carpeting the sea bottom near Arrival Heights and other sites around McMurdo Sound (Dayton et al. 1974). Populations of the omnivorous sea star Odontaster validus may attain mean densities of 13 ind. $\mathrm{m}^{-2}$ at Cape Evans on Ross Island in McMurdo Sound (McClintock et al. 1988, McClintock 1994) and dense populations of $O$. validus are likely to form a 'larval filter' through which settling larvae and young juveniles must pass (Dayton et al. 1974). O. validus has been suggested to regulate recruitment success in spongivorous sea stars by preying on early recruits, thereby regulating the structure of the antarctic sponge community (Dayton et al. 1974). The findings of our study would imply that it is more likely predation occurs on post-settlement juveniles in $P$. fuscus, as $O$. validus rejected both their embryos and larvae.

High levels of benthic predation are likely to select for defensive attributes in antarctic benthic lecitho- 
trophic embryos and larvae. We found that the large orange embryos of the brooding sea star Diplasterias brucei and the brooded bright yellow eggs of the antarctic sponge Isodictya setifera were unpalatable to 2 and 3 sympatric invertebrate predators, respectively. While many brooded sponge eggs were imbedded in exposed outer surfaces where they would be vulnerable to predators, brooded sea star embryos were well protected physically by brooding adult females. It is likely that chemical deterrents are retained until the juvenile phase, when young sea stars crawl free of their parent and are exposed to predation. The brooded embryos of the sea star $D$. brucei are also noxious to an allopatric fish, as were the eggs of several other antarctic echinoderms (McClintock \& Vernon 1990). While no information on chemical defense in antarctic sponge larvae is available, Lindquist (1996) and Lindquist \& Hay (1996) found the larvae of 17 out of 21 Caribbean sponges to be unpalatable to invertebrate or fish predators. Moreover, gelatinous egg ribbons containing developing embryos of the nudibranch Tritoniella belli were unpalatable to the sea star Odontaster validus (see also Pawlik et al. 1988), while the nudibranch egg ribbons were consumed by the amphipod Paramoera walkeri and the sea anemone Isotealia antarctica. Once again, for the reasons given above, we feel it is likely that defense in conspicuous yolky benthic eggs and embryos is likely to be chemically based. While our present study demonstrates that chemical defense is responsible for feeding deterrence in the brooded embryos of the sea star $D$. brucei, and that chemical defense does not occur in the planktotrophic eggs, embryos and larvae of the broadcast spawning $O$. validus and Sterechinus neumayeri, further studies are needed to evaluate whether chemical defense is responsible for the deterrent properties in additional brooded or pelagic lecithotrophic eggs, embryos and larvae of antarctic marine invertebrates. Moreover, while the nature of defensive secondary metabolites has been investigated in select adult antarctic marine invertebrates (e.g. McClintock et al. 1994a, b, Baker et al. 1995, Bryan et al. 1995, Jayatilake et al. 1995, McClintock \& Baker in press), similar information on marine invertebrate eggs, embryos and larvae is needed.

Acknowledgements. We thank the Antarctic Support Associates, the US Naval Antarctic Support Force and the National Science Foundation for logistical support. Adam Marsh, Jim Mastro, Chris Moeller, Dom Tedeshi, Jenni Kreider and Pat Bryan assisted with collections and/or bioassays. Chuck Amsler suggested the amphipod assays and assisted in their collection as well as provided constructive comments on the manuscript. Gamini Jayatilake performed the chemical extractions. This research was supported by NSF Grants OPP9118864 and OPP-9530735 to J.B.M. and OPP-9117216 and OPP-9526610 to B.J.B. The paper is dedicated to the memory of Charles G. McClintock.

\section{LITERATURE CITED}

Alexander SE, Roughgarden J (1996) Larval transport and population dynamics of intertidal barnacles: a coupled benthic/oceanic model. Ecol Monogr 66:259-276

Arnaud PM (1974) Contribution a la bionomie marine benthique des régions antarctiques et subantarctiques. Tethys $6: 468-653$

Bailey KM (1984) Comparison of laboratory rates of predation on five species of marine fish by 3 planktonic invertebrates: effects of larval size on vulnerability. Mar Biol 79: 303-309

Baker BJ, Kopitzke RJ, Yoshida WY, McClintock JB (1995) Chemical and ecological studies of the antarctic sponge Dendrilla membranosa. J Nat Prod 58:1459- 1462

Bakus GJ, Targett NM, Schulte B (1986) Chemical ecology of marine organisms: an overview. J Chem Ecol 12:951-987

Bingham BL, Walters LJ (1989) Solitary ascidians as predators of invertebrate larvae: evidence from gut analyses and plankton samples. J Exp Mar Biol Ecol 131:147-159

Bosch I (1989) Contrasting modes of reproduction in 2 antarctic asteroids of the genus Porania with a description of unusual feeding and non-feeding larval types. Biol Bull (Woods Hole) 177:77-82

Bosch I, Beauchamp KB, Steele MS, Pearse JS (1987) Development, metamorphosis, and seasonal abundance of embryos and larvae of the antarctic sea urchin Sterechinus neumayerl. Biol Bull (Woods Hole) 173:126-135

Bosch I, Pearse JS (1990) Developmental types of shallowwater asteroids of McMurdo Sound, Antarctica. Mar Biol 104:41-46

Brey T, Pearse JS, Basch L, McClintock JB, Slattery M (1995) Growth and production of Sterechinus neumayeri (Echinodea: Echinodermata) in contrasting habitats of McMurdo Sound, Antarctica. Mar Biol 124:279-292

Bryan PJ, Yoshida WY, McClintock JB, Baker BJ (1995) An ecological role for pteroenone, a novel antifeedant produced by the conspicuous pteropod Clione antarctica (Gymnosomata: Gastropoda). Mar Biol 12:271-278

Clarke A (1982) Temperature and embryonic development in polar marine invertebrates. Invert Repro Develop 5:71-82

Cowden C, Young CM, Chia FS (1984) Differential predation on marine invertebrate larvae by two benthic predators. Mar Ecol Prog Ser 14:145-149

Dayton PK, Oliver JS (1977) Antarctic soft-bottom benthos in oligotrophic and eutrophic environments. Science 197: $55-58$

Dayton PK, Robilliard GA, Paine RT, Dayton LB (1974) Biological accommodation in the benthic community at McMurdo Sound, Antarctica. Ecol Monogr 44:105-128

Dell RK (1972) Antarctic benthos. Adv Mar Biol 10:1-216

Eastman JT (1993) Antarctic fish biology: evolution in a unique environment. Academic Press. Inc, New York

Eckman JE (1996) Closing the larval loop: linking larval ecology to the population dynamics of marne benthic invertebrates. J Exp Mar Biol Ecol 200:207-237

Emlet RB, McEdward LR, Strathmann RR (1987) Echinoderm larval ecology viewed from the egg. In: Jangoux $M$, Lawrence JM leds) Echinoderm studies, Vol 2. AA Balkema Press, Rotterdam, p 55-136

Foster BA (1987) Composition and abundance of zooplankton under the spring sea-ice at McMurdo Sound, Antarctica. Polar Biol 8:41-48

Gaines D, Roughgarden J (1985) Larval settlement rate: a leading determinant of structure in an ecological community of the marine intertidal zone. Proc Natl Acad Sci USA 82:3707-3711 
Garrison DL (1991) Antarctic sea ice biota. Am Zool 31:17-33 Harbison GR (1988) Observations on the epipelagic gelatinous fauna of McMurdo Sound. Antarct J US 23:135

Hay ME (1996) Marine chemical ecology: what's known and what's next? J Exp Mar Biol Ecol 200:103-134

Jablonski D, Lutz RA (1983) Larval ecology of marine benthic invertebrates: paleobiological implications. Biol Rev 58 $21-89$

Jangoux M (1982) Asteroidea. In: Jangoux M, Lawrence JM (eds) Echinoderm nutrition. A.A Balkema Press, Rotterdam, p 117-159

Jayatilake GS, Baker BJ, MCClintock JB (1995) 1, 3, 4'-triacetoxystilbene, a plant growth regulator, from the antarctic sponge Kirkpatrickia variolosa. J Nat Prod 58:1958-1960

Lindquist N (1996) Palatability of invertebrate larvae to corals and sea anemones. Mar Biol 126:745-755

Lindquist N, Hay ME (1996) Palatability and chemical defense of marine invertebrate larvae. Ecol Monogr 66 $431-450$

Lindquist N, Hay ME, Fenical W (1992) Defense of ascidians and their conspicuous larvae: adult vs larval chemical defenses. Ecol Monogr 62:547-568

Lucas JS, Hart RJ, Howden Mt, Salathe R (1979) Saponins in eggs and larvae of Acanthaster planci (L.) (Asteroidea) as chemical defenses against planktivorous fish. J Exp Mar Biol Ecol 40:155-165

McClintock JB (1994) The trophic biology of antarctic echinoderns. iviar Ecoi Prog Ser i i 1:ị̂i-zuz

McClintock JB, Baker BJ (in press) An overview of the chemical ecology of antarctic marine invertebrates. Am Zool

McClintock JB, Baker B, Hamann MT, Yoshida W. Slattery M, Heine JN, Bryan PJ, Jayatilake GS, Moon BH (1994a) Homarine as a feeding deterrent in the common shallowwater antarctic lamellarian gastropod Marseniopsis mollis: a rare example of chemical defense in a marine prosobranch. J Chem Ecol 20:2539-2549

McClintock JB, Baker B. Slattery M, Heine JN, Bryan PJ, Yoshida W, Davies-Coleman MT, Faulkner DJ (1994b) Chemical defense of the common antarctic shallow-water nudibranch Tritoniella belli (Mollusca: Tritonidae) and its prey, Clavularia frankliniana Rouel (Cnidaria: Octocorallia). J Chem Ecol 20:3361-3372

McClintock JB, Jansson J (1990) Pteropod abduction as a chemical defense in a pelagic antarctic amphipod. Nature 346:462-464

McClintock JB, Pearse JS (1986) Organic and energetic content of eggs and juveniles of antarctic echinoids and asteroids with lecithotrophic development. Comp Biochem. Physiol 85A:341-345

McClintock JB, Pearse JS, Bosch I (1988) Population structure and energetics of the common antarctic sea star Odontaster validus. Mar Biol 99:235-246

McClintock JB, Vernon J (1990) Chemical defense in the eggs and embryos of antarctic sea stars. Mar Biol 105:491-495

Mileikovsky SA (1971) Types of larval development in marine bottom invertebrates, their distribution, and ecological significance: a re-evaluation. Mar Biol 10:193-213

Morgan SG (1990) Predation by planktonic and benthic invertebrates on larvae of estuarine crabs. J Exp Mar Biol Ecol 163:91-110

Morgan SG (1995) Life and death in the plankton: larval mortality and adaptation. In: McEdward L (ed) Ecology of marine invertebrate larvae. CRC Press, Boca Raton, FL, p 279-322

Okubo A (1994) The role of diffusion and related physical processes in dispersal and recruitment of marine populations. In: Sammarco PW. Heron ML (eds) The bio-physics of marine larval dispersal. American Geophysical Union, Washington, DC, p 5-34

Olafsson EB, Peterson CH, Ambrose WG Jr (1994) Does recruitment limitation structure populations and communities of macro-invertebrates in marine soft sediments: the relative significance of pre- and post-settlement processes. Oceanogr Mar Biol Annu Rev 32:65-109

Oliver JS, Oakden JM, Slattery PN (1982) Phoxocephalid amphipod crustaceans as predators on larvae and juveniles in marine bottom communities. Mar Ecol Prog Ser 7:179-184

Paul VJ (1992) Ecological roles of marine natural products. Comstock, Ithaca

Pawlik JR (1993) Marine invertebrate chemical defenses. Chem Rev 93:1911-1922

Pawlik JR, Kernan MR, Molinski TF, Harper MK, Faulkner DJ (1988) Defensive chemicals of the Spanish Dancer nudibranch, Hexabranchus sanguineus, and its egg ribbons: macrolides derived from a sponge diet. J Exp Mar Biol Ecol 119:99-109

Pearse JS (1965) Reproductive periodicities in several contrasting populations of Odontaster validus Koehler, a common antarctic asteroid. Antarct Res Ser 5:39-85

Pearse JS, McClintock JB, Bosch I (1991) Reproduction of antarctic benthic marine invertebrates: tempos, modes and timing. Am Zool 31:65-80

Picken GB (1980) Reproductive adaptations of antarctic benthic invertebrates. Biol J Linn Soc 14:67-75

Purcell JE (1989) Predation on fish larvae and eggs by the hydromedusae (Aequorea victoria) at a herring spawning ground in British Columbia. Can J Fish Aquat Sci 46: $1415-1427$

Rakusa-Suszczewski S (1972) The biology of Paramoera walkeri Stebbing (Amphipoda) and the Antarctic sub-fast ice community. Pol Arch Hydrobiol 19:11-36

Roughgarden J (1989) The evolution of marine life cycles. In: Feldman MW (ed) Mathematical evolutionary theory. Princeton University Press, Princeton, NJ, p 270-300

Roughgarden J, Gaines S, Possingham S (1988) Recruitment dynamics in complex life cycles. Science 241:1460-1466

Roughgarden J, Iwasa Y, Baxter C (1995) Demographic theory for an open marine population with space-limited recruitment. Ecology 66:54-67

Rumrill SS (1990) Natural mortality of marine invertebrate larvae. Ophelia 32:163-198

Shanks AL (1995) Mechanisms of cross-shelf dispersal of larval invertebrates and fish. In: McEdward L (ed) Ecology of marine invertebrate larvae. CRC Press, Boca Raton, FL, p $323-368$

Stevens M (1970) Procedures for induction of spawning and meiotic maturation of starfish oocytes by treatment of 1 methyladenine. Exp Cell Res 59:481-484

Strathmann RR (1985) Feeding and non-feeding larval development and life-history evolution in marine invertebrates Annu Rev Ecol Syst 16:339-361

Strathmann RR, Strathmann MF (1982) The relationship between adult size and brooding in marine invertebrates. Am Nat 119:91-101

Timko P (1979) Larviphagy and oophagy in benthic invertebrates: a demonstration for Dendraster excentricus (Echinoidea). In: Stancyk SE (ed) Reproductive ecology of marine invertebrates. University of South Carolina Press, Columbia, p $91-98$

Thorson GL (1950) Reproductive and larval ecology of marine bottom invertebrates. Biol Rev 25:1-45

Underwood A.J, Denley EJ (1984) Paradigm, explanations and generalizations in models for the structure of intertidal communities on rocky shores. In: Simberloff D 
Strong DR, Able L, Thistle AR (eds) Ecological communities: conceptual issues and the evidence. University Press, Princeton, NJ, p 151-180

Valentine JW, Jablonski D (1983) Larval adaptations and patterns of brachiopod diversity in space and time. Evolution 37:1052-1061

Vance RR (1973) On reproductive strategies in marine benthic invertebrates. Am Nat 107:339-352

White MG (1984) Marine benthos. In: Law RM (ed) Antarctic ecology, Vol 2. Academic Press, London, p 421-461

This article was presented by Joseph Pawlik (Senior Editorial Advisor), Wilmington, North Carolina, USA
Young CM, Bingham BL (1987) Chemical defense and aposematic coloration in larvae of the ascidian Ecteinascidia turbinata. Mar Biol 96:539-544

Young CM. Chia FS (1987) Abundance and distribution of pelagic larvae as influenced by predation, behavior and hydrographic factors. In: Giese AC, Pearse JS, Pearse VB (eds) Reproduction of marine invertebrates. Blackwell, Palo Alto, CA, p 385-463

Zar J (1996) Biostatistical analysis, 3rd edn. Prentice Hall, Upper Saddle River, NJ

Manuscript recesved: March 13, 1997

Revised version accepted: June 6, 1997 